\title{
Avalanche fatalities in the European Alps: long-term trends and statistics
}

\author{
Frank Techel ${ }^{1}$, Frédéric Jarry ${ }^{2}$, Georg Kronthaler ${ }^{3}$, Susanna Mitterer ${ }^{4}$, Patrick Nairz ${ }^{5}$, Miha Pavšek ${ }^{6}$, \\ Mauro Valt ${ }^{7,8}$, and Gian Darms ${ }^{1}$ \\ ${ }^{1}$ WSL Institute for Snow and Avalanche Research SLF, Davos, Switzerland \\ ${ }^{2}$ Association Nationale pour l'Étude de la Neige et des Avalanches, Grenoble, France \\ ${ }^{3}$ Lawinenwarndienst Bayern, Munich, Germany \\ ${ }^{4}$ Österreichisches Kuratorium für alpine Sicherheit, Innsbruck, Austria \\ ${ }^{5}$ Lawinenwarndienst Tirol, Innsbruck, Austria \\ ${ }^{6}$ Anton Melik Geographical Institute, Research Centre of the Slovenian Academy of Sciences and Arts, \\ Ljubljana, Slovenia \\ ${ }^{7}$ Associazione Interregionale Neve e Valanghe, Trento, Italy \\ ${ }^{8}$ Centro Valanghe di Arabba, Arabba, Italy \\ Correspondence to: Frank Techel (techel@slf.ch)
}

Received: 21 March 2016 - Revised: 16 June 2016 - Accepted: 21 June 2016 - Published: 28 June 2016

Abstract. Avalanche accidents, particularly those resulting in fatalities, attract substantial attention from policy makers and organizations, as well as from the media and the public. Placing fatal accidents in a wider context requires long-term and robust statistics. However, avalanche accident statistics, like most other accident statistics, often rely on relatively small sample sizes, with single multi-fatality events and random effects having a potentially large influence on summary and trend statistics. Additionally, trend interpretation is challenging because statistics are generally explored at a national level, and studies vary in both the period covered and the methods. Here, we addressed these issues by combining the avalanche fatality data from the European Alps (Austria, France, Germany, Liechtenstein, Italy, Slovenia, and Switzerland) for three different periods between 1937 and 2015 and applying the same data analysis methodology. During the last four decades, about 100 people lost their lives each year in the Alps. Despite considerable inter-annual variation, this number has remained relatively constant in the last decades. However, exploring fatality numbers by the location of the victims at the time of the avalanche revealed two partly opposing trends. The number of fatalities in controlled terrain (settlements and transportation corridors) has decreased significantly since the 1970s. In contrast to this development, the number of fatalities in uncontrolled terrain (mostly recreational accidents) almost doubled between the 1960s and 1980s and has remained relatively stable since then, despite a strong increase in the number of winter backcountry recreationists. Corresponding to these trends, the proportion of fatalities in uncontrolled terrain increased from 72 to $97 \%$. These long-term trends were evident in most national statistics. Further, the temporal correlation between subsets of the Alpine fatality data, and between some of the national statistics, suggests that time series covering a longer period may be used as an indicator for missing years in shorter-duration datasets. Finally, statistics from countries with very few incidents should be compared to, or analysed together with, those from neighbouring countries exhibiting similar economical and structural developments and characteristics. 


\section{Introduction}

For centuries, snow avalanches have been a hazard to people living, working, travelling, and recreating in the Alps (Laternser and Pfister, 1997; Ancey et al., 1998). The earliest documented measures to reduce the avalanche risk to people and objects in the Alps go back to at least the 14th century (e.g. laws to protect forests above avalanche-endangered settlements; Margreth, 2004). In the 20th century, the protection of settlements and transportation corridors was intensified (e.g. WSL, 2000; Höller, 2007). At the same time, the increased recreational use of the Alps, and subsequently more recreationists dying in avalanches, necessitated further developments, for instance in avalanche rescue and avalanche education. The effectiveness of preventive measures (e.g. Fuchs et al., 2004), avalanche rescue equipment (e.g. Tschirky et al., 2000; Brugger et al., 2001; Haegeli et al., 2014), avalanche education and publicly available avalanche forecasts (e.g. Etter et al., 2008; Harvey and Zweifel, 2008; Valt and Pivot, 2013), or rule-based decision frameworks (e.g. Munter, 1997; McCammon and Hägeli, 2007) is often explored using avalanche accident statistics as the fundamental data source.

When and where an avalanche accident occurs relies not only on snowpack and avalanche conditions (e.g. Jamieson et al., 2010; Harvey, 2002; Valt, 2009) but also on the number of exposed elements (Techel et al., 2015b). Whether an avalanche results in a fatality depends on the size of the avalanche, the location of the victim in relation to the avalanche, and terrain obstacles, which might cause severe traumatic injuries (Brugger et al., 2001; Jamieson and Jones, 2015). In addition, accidents in general, are considered unexpected and "unpredictable" (Fridstrom et al., 1995, p. 2) and are therefore, to a certain degree, considered random events.

The interpretation of avalanche accident data is further complicated because statistics often rely on a relatively small number of events (e.g. 153 reported avalanche accidents involving people in Switzerland in 2014/2015 (Techel et al., 2015a), compared to 17803 traffic accidents in Switzerland in 2014; Bundesamt für Statistik, 2016). Further, the severity of incidents influences the reporting rate: accidents resulting in casualties are generally well reported and documented, and less-severe incidents are often underreported (e.g. Meister, 1987; Edgerly, 2010; Jamieson and Jones, 2015). Additionally, regional and temporal variations in the reporting rate must be considered (Techel and Zweifel, 2013). Lastly, data interpretation is challenging because avalanche accident statistics are normally compiled and explored at a national level, each considering different periods and datasets, and apply variable data exploration methods (e.g. Page et al., 1999; Valt, 2009; Jarry, 2011). Data aggregation at a larger level, such as statistics collected by the International Commission on Alpine Rescue (ICAR-CISA, e.g. Etter et al., 2004; ICAR-CISA, 2016), is rarely completed. Thus, it is not surprising that avalanche statistics, in particular those that cover only data from countries with few incidents and/or a short duration or with distinct cultural and social influences, sometimes show considerable differences. For instance, decreasing fatality numbers over time were noted in Switzerland (years 1977-2006; Harvey and Zweifel, 2008) and Italy (1985-2009; Valt, 2009), while in France no significant changes were observed (1971-1998; Sivardiére, 1998). Etter et al. (2004), who included the statistics from all the ICAR-CISA countries (including for instance North America) deduced trends based on a 20-year time series (19842003). The authors concluded that there was an increase in the fatality numbers in Austria, and Switzerland, but they acknowledged that the catastrophic winter 1998/1999 probably had a large influence on this trend.

In the present study, we addressed these issues by aggregating and comparing the avalanche fatality data from seven Alpine countries. For all countries, we applied the same methodology and explored comparable periods. As data on the number of exposed elements were not available, we purely analysed the number of avalanche fatalities.

\section{Data and methods}

\subsection{Definition of avalanche accidents}

The definition of an accident depends on the discipline investigated (Kirchsteiger, 1999). Generally, accidents are defined based on adverse consequences (like fatal or non-fatal injury), by lost work time (occupational accidents, e.g. ILO, 2012), or by other damage inflicted (e.g. Kirchsteiger, 1999). For the purpose of this analysis, we defined an avalanche accident as one caused by a snow avalanche that resulted in at least one fatality. We excluded ice avalanches (like serac falls) and cornice falls where no snow avalanche was triggered. Roof avalanches were also excluded.

\subsection{Data}

The data comprised avalanche fatality data from the Alpine regions in the seven countries Austria, France, Germany, Italy, Liechtenstein, Slovenia, and Switzerland. The national datasets differed in length, starting between the years 1937 and 1970 and continuing to 2015 (Table 1), and in which details were available. As a minimum, each national time series provided information on the annual number of casualties that occurred at a given location and the activity of the victims when the accident occurred. Therefore, we restricted our analysis to these two parameters. Following feedback from the respective database managers, the data can be considered complete for the years shown in Table 1.

We limited the analysis to accidents occurring in the Alps, according to the definition of the Alps used in the Alpine Convention (2009). Thus, avalanche fatalities occurring outside the Alpine regions, for example in the Vosges or Pyrenees (FRA), the Jura (CHE/FRA), the Black Forest (DEU), 
Table 1. Overview of available avalanche fatality data from seven Alpine countries, the corresponding country abbreviation (ISO-31662 country code), the list of the mountain regions not considered in this analysis, and the approximate percentage of the Alpine surface area according to the Alpine Convention (Alpine surface area $190000 \mathrm{~km}^{2}$, Alpine Convention, 2009). Monaco (percentage of surface area $0.001 \%$ ) is not shown because there were no data on avalanche fatalities available for this country.

\begin{tabular}{|c|c|c|c|c|}
\hline Country & Period & Data source & Mountain regions excluded & $\begin{array}{l}\text { Proportion } \\
\text { of Alpine } \\
\text { surface }\end{array}$ \\
\hline AUT: Austria & $1950-2015$ & various sources* & & $28.7 \%$ \\
\hline CHE: Switzerland & $1937-2015$ & $\begin{array}{l}\text { WSL - Institut für Schnee- und } \\
\text { Lawinenforschung (SLF) }\end{array}$ & Jura & $13.2 \%$ \\
\hline DEU: Germany & $1967-2015$ & Lawinenwarndienst Bayern & Black Forest & $5.8 \%$ \\
\hline FRA: France & 1970-2015 & $\begin{array}{l}\text { Association Nationale pour l'Étude de } \\
\text { la Neige et des Avalanches (ANENA) }\end{array}$ & $\begin{array}{l}\text { Pyrenees, Vosges, Jura, } \\
\text { Massif Central, Corsica }\end{array}$ & $21.4 \%$ \\
\hline ITA: Italy & $1967-2015$ & $\begin{array}{l}\text { Associazione Interregionale Neve e } \\
\text { Valanghe (AINEVA); Centro Valanghe } \\
\text { di } \\
\text { Arabba }\end{array}$ & $\begin{array}{l}\text { Apennines, Mediterranean } \\
\text { islands }\end{array}$ & $27.2 \%$ \\
\hline LIE: Liechtenstein & 1970-2015 & $\begin{array}{l}\text { Amt für Bevölkerungsschutz Liechten- } \\
\text { stein }\end{array}$ & & $0.08 \%$ \\
\hline SVN: Slovenia & 1950-2015 & $\begin{array}{l}\text { Anton Melik Geographical Institute, } \\
\text { Research Centre of the Slovenian } \\
\text { Academy of Sciences and Arts }\end{array}$ & & $3.6 \%$ \\
\hline
\end{tabular}

* Data sources for Austria: Höller (2007, 2015); Schaffhauser (1988); Luzian (1992, 2000), Lawinenwarndienst Tirol, Österreichisches Kuratorium für alpine Sicherheit, SLF (1950-1980).

or the Apennines (ITA), were excluded (see also Table 1). The Italian data for the years between 1967 and 1977, where no information on the geographical location was available, were treated as if all accidents had occurred in the Alpine region.

In the Northern Hemisphere, avalanche accident data are collected and analysed by hydrological year, which starts on 1 October and ends on 30 September. The notation we used refers to the hydrological year 1969/1970 as 1970 .

Based on the availability of the data, we combined national statistics to obtain the largest possible dataset for each of three time intervals. We analysed fatality data spanning 79 years (Switzerland), 66 years (Austria, Slovenia, and Switzerland), and 46 years (all Alpine countries).

\subsection{Accident location and activity}

Avalanche fatalities were classified according to the location of the accident party at the time of the avalanche accident. This classification has been common practice for many decades (e.g. Valla, 1984; Meister, 1987), and it is also used by ICAR-CISA (e.g. Etter et al., 2004; ICAR-CISA, 2016). Several categories of locations and activities are summarized within the two main groups controlled terrain and uncontrolled terrain (e.g. Meister, 1987):
- Controlled terrain fatalities involve people killed by avalanches within settlements or in isolated permanent or temporary buildings, as well as those killed while on transportation corridors (for instance roads, railways, ski runs, signed and groomed winter hiking trails). Victims typically belong to one of four groups: (i) people travelling or recreating on open or temporarily closed transportation corridors (e.g. a road user or a skier on a ski run), (ii) people working on open or closed transportation corridors (e.g. maintenance crews on roads, professional rescue teams), (iii) people inside or just outside buildings, and (iv) workers on high alpine building sites. Generally, some kind of authority (e.g. a road or ski area management or a communal avalanche commission) is responsible for the safety of people in these locations and must incorporate the appropriate avalanche safety measures to reduce the risk. These avalanches release in many cases naturally (Badoux et al., 2016).

- Uncontrolled terrain covers terrain outside settlements and away from transportation corridors. Activities of victims killed in fatal accidents related to avalanches are mostly of the recreational type (e.g. hiking, mountaineering, ski- or snowshoe-touring and off-piste riding). Guided activities, rescue operations, and ski pa- 
trolling carried out away from transportation corridors and settlements also fall into this category. In uncontrolled terrain, the recreationists or the group's professional guide is responsible for assessing and mitigating the local avalanche danger. Thus, individuals are responsible for their personal safety while recreating or working in uncontrolled terrain (Stethem et al., 2003, "voluntary risk", p. 496). In the vast majority of cases, accidental avalanches are triggered by the accident party (Schweizer and Lütschg, 2001).

\subsection{Statistical methods}

Mean, median, minimum, and maximum values were employed to describe the data.

Besides descriptive statistics, we were interested in longterm trends, serial correlation, significant peaks, and low points in the time series.

Auto-correlation: Each time series - those combining several countries as well as subsets of the data (e.g. uncontrolled terrain only or single countries) - was checked for autocorrelation (Venables and Ripley, 2002). Significant autocorrelation with a lag of 1 to 5 years was common, particularly in the subsets controlled and uncontrolled terrain.

Inter-annual variability: The coefficient of variation $(\mathrm{CV}$, ratio of standard deviation to mean; Boslaugh and Watters, 2008) was used as a measure of the annual variability of the fatality numbers compared to the long-term mean. We used the $\mathrm{CV}$ for the 46-year Alpine dataset $(\mathrm{CV}=30 \%)$ as a base value to compare the inter-annual variability of different time series. Specifically, we compared the proportion of years where the number of fatalities was within the $\pm 30 \%$ range of the respective time series' 46-year mean (rounded to the nearest integer).

Significant peaks and low points in the time series: Annual variability and serial correlation were observed in part of the data. For example, a significant lag of 12 years was found in the 79-year time series for uncontrolled terrain in Switzerland (positive correlation) and a lag of 11 years was found for the 46-year time series for uncontrolled terrain in the entire Alps (negative correlation). To account for these issues, running means and medians were calculated for 15year periods. We consider these relatively robust measures for reducing the influence of single extreme years. The running means and medians were checked for significant peaks and low points using the turning point approach (Grosjean and Ibanez, 2014).

Cross-correlation between data subsets - e.g. correlation between the 66-year Swiss and Austrian datasets - was tested using a cross-correlation function (Venables and Ripley, 2002).

Time series were examined for monotonic trends by applying the non-parametric Mann-Kendall trend test (Mann, 1945; McLeod, 2011).
Significant differences between populations were determined by applying the Wilcoxon rank-sum test (Boslaugh and Watters, 2008).

Test results were considered significant if $p<0.05$.

The whole analysis was conducted using the statistics software R (R Core Team, 2016).

\section{Results}

We present the results in three sections: the longest period (79 years) including just one country (CHE, Sect. 3.1), followed by the 66-year period (AUT, CHE, SVN; Sect. 3.2), and finally the 46-year period including data for the seven Alpine countries (Sect. 3.3). Descriptive statistics, trends, and turning points are given for the respective subsets of the data. Additionally, we provide information on the crosscorrelation between countries.

\subsection{Swiss Alps: 1937-2015}

During the 79 years in this time series (1937-2015), 1958 people lost their lives in avalanches in the Swiss Alps, with an annual mean of 24.8 per year (median $23, \min 1$, max 99). The overall number of avalanche fatalities showed no significant temporal trend. Several turning points in the dataset were identified, the most prominent being the minimum in 1953 (years 1946-1960: median 13, mean 20) followed by an almost continuous increase until the 1970s and reaching a maximum in 1984 (1977-1991: median 28, mean 31; Fig. 1, upper plot). After the peak in 1984, the median and mean were consistently lower in the succeeding years. The annual number of fatalities during the 15 -year period surrounding the maximum in 1984 was significantly higher than during the last 15 years of the time series $(2001-2015, p=0.04)$ indicating a slight decrease in the number of fatalities over time.

Over the whole period, the number of fatalities in controlled terrain showed a significantly decreasing trend $(p<$ 0.001 ) and the number in uncontrolled terrain showed a significantly increasing trend $(p<0.001)$. However, trends were not uniform throughout this period. Casualty numbers in controlled terrain started to drop significantly from 1970 onwards (1937-1976: median 5, 1977-2015: median $1, p<0.001$ ), while fatality numbers in uncontrolled terrain tripled in the 33 years between 1953 (1946-1961: median 8 ) and 1986 (1979-1994: median 26, $p<0.001)$. In uncontrolled terrain, neither the decrease in fatality numbers in the 1990s (1987-2001: median 19), nor the following increase to the most recent 15 years (2001-2015: median 24) was statistically significant.

The Swiss data comprised about one-quarter of the avalanche fatalities in the Alps (Table 2, years 1970-2015) and occurred on $13 \%$ of the Alpine surface area (Table 2). 
Table 2. Avalanche fatality summary statistics by country for the 46 years between 1970 and 2015 . The annual median/mean, the range (minimum to maximum), the coefficient of variation CV (in \%, ratio of standard deviation to mean), and the proportion of fatalities in uncontrolled terrain are shown.

\begin{tabular}{lllll}
\hline Data & Median/mean & Min-max & CV (\%) & Uncontrolled (\%) \\
\hline AUT & $23 / 26.3$ & $3-61$ & 50 & 76 \\
CHE & $25 / 26.1$ & $11-56$ & 39 & 87 \\
DEU & $1.5 / 2.5$ & $0-9$ & 97 & 93 \\
FRA & $25.5 / 27.3$ & $8-58$ & 41 & 89 \\
ITA & $18 / 19.5$ & $5-43$ & 50 & 83 \\
LIE & $0 / 0.2$ & $0-3$ & 328 & 100 \\
SVN & $1 / 1.4$ & $0-8$ & 142 & 85 \\
\hline AUT-CHE-SVN & $51 / 53.8$ & $21-98$ & 37 & 84 \\
\hline Alps & $99.5 / 103.3$ & $54-179$ & 30 & 86 \\
\hline
\end{tabular}

\subsection{Austrian, Slovenian, and Swiss Alps: 1950-2015}

During the 66 years in this time series (1950-2015), avalanches killed 3729 people in the Austrian, Swiss, and Slovenian Alps (annual mean 56.5, median 50, min 21, max 235). Two of the most catastrophic avalanche winters in the 20th century occurred at the beginning of this period (1951: 235 fatalities in AUT and CHE; 1954: 176 fatalities, mostly in AUT). While the other Alpine countries are not discussed in this section, some also experienced a catastrophic winter in 1951 that resulted in many fatalities (e.g. ITA 46 fatalities; Roch, 1980). In SVN, the largest number of casualties was recorded in 1952 (19 fatalities).

As for the 79-year Swiss data, the overall number of avalanche fatalities in this dataset showed no significant temporal trend (Fig. 1, middle plot). Following the maximum of the 15-year median in the years 1968 to 1971 (median 64), the median number of fatalities was lower throughout the following 40 years. In contrast, the 15 -year mean showed a second peak in 1980 (mean 60) followed by a decrease. Although both the 15-year mean values (between 47 and 55) and the 15-year median values (between 48 and 55) were lower in the decades which followed these peaks, this reduction in avalanche fatalities was not significant $(p>0.05)$. In this 66-year dataset, the number of fatalities in controlled terrain showed a significantly decreasing trend $(p<0.001)$ and the group uncontrolled terrain showed a significantly increasing trend $(p<0.001)$ (Fig. 2a, b). These trends were mirrored in the temporal distribution of the years with the highest number of fatalities. In controlled terrain, these years occurred almost exclusively during the first half of the 66year period (before 1984, 9 of 10), as compared to uncontrolled terrain, where 8 of 10 occurred in the second half (after 1983). The fatalities in uncontrolled terrain almost doubled between the beginning of the 1960s and the late 1980s (median 1954-1968: 23, median 1980-1994: 45, $p<0.01$ ), a trend that was more pronounced in CHE than in AUT. Since then, fatality numbers have remained relatively stable with no significant change compared to the final 15 years of this time period (Fig. 2b). The 66-year Swiss and Austrian-Slovenian time series showed a significant cross-correlation $(p<0.01$, lag $=0$ years $)$ for the time series considering all fatalities, and the subsets controlled and uncontrolled terrain.

The combined dataset AUT, CHE, and SVN included slightly more than $50 \%$ of the avalanche fatalities in the entire Alps (Table 2, for years 1970-2015) and occurred on $45 \%$ of the Alpine surface area (Table 1).

\subsection{European Alps: 1970-2015}

A total of 4750 people lost their lives in the European Alps in the 46 years between 1970 and 2015 (annual mean 103.3, median 99.5, min 54, max 179; Table 2). The dataset commenced in 1970, when statistics from all seven countries were available. As a comparison with Fig. 1 (middle plot) shows, the year 1970 was in the period with the highest 15year median for the Austrian-Swiss-Slovenian data; 1970 was also the worst year in the French Alps (58 fatalities) and the second-worst year in the more recent Italian history (37 fatalities). The highest number of fatalities in the German Alps was recorded in 1965 (10 fatalities) and was thus outside of the investigated period.

As Fig. 1 (lower plot) indicates, the overall number of avalanche fatalities showed no significant temporal trend. Similarly, the 15-year running median was relatively stationary. No significant turning points were detected. The 15 -year running mean indicated several turning points with an absolute peak and turning point in 1984 (1977-1991: mean 114) and a low point in 1995 (1988-2002: mean 93). However, neither the annual number of fatalities in the 15 years surrounding this peak and low point, nor the following increase (2001-2015: median 103) was significantly different $(p>0.05)$.

The number of avalanche fatalities in controlled terrain showed a significantly decreasing trend during this 46-year time series $(p<0.001$, Fig. $2 c)$. The fatality numbers de- 

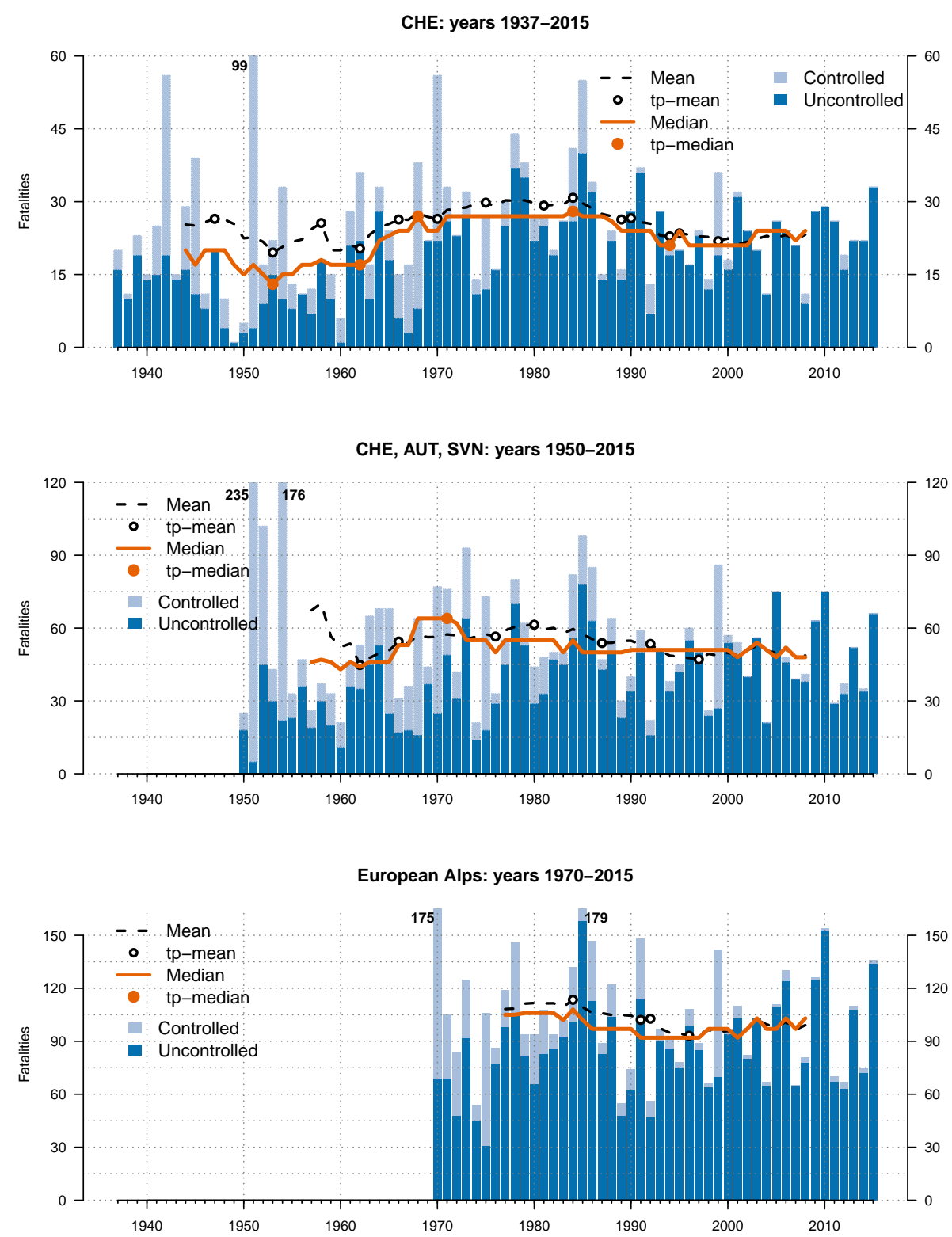

Figure 1. Avalanche fatalities in each hydrological year for three datasets spanning different periods: Switzerland (CHE), 1937-2015 (upper plot); Switzerland, Austria, and Slovenia (CHE, AUT, SVN), 1950-2015 (middle plot); and the whole Alps, 1970-2015 (lower plot). For each dataset, fatalities in controlled (light blue) and uncontrolled terrain (dark blue) are indicated. The 15-year moving means and the 15year moving medians for the combined data (controlled and uncontrolled terrain) are shown. Significant $(p<0.05)$ turning points (tp) for the mean and median curves are marked with circles. In years when the annual number of fatalities exceeded the limit of the selected $y$ axis, the fatality number is shown at the top of the bar.

creased from the first to the last 15 years (1970-1984: median 28 per year, 2001-2015: 2 per year, $p<0.001$ ). This decrease was mirrored in the distribution of the 10 years with the largest number of fatalities ( 9 of 10 occurred during the first 23 years). In contrast, in uncontrolled terrain, the worst years were recorded predominantly in the second half of the period (6 of 10). In addition, the number of avalanche fatalities in uncontrolled terrain was greater in the final 15 years (median 103) compared to the first 15 years (1970-1984: me- dian 82). However, neither the monotonic trend $(p=0.07)$, nor the difference in the number of fatalities $(p=0.11)$ of these two 15-year periods was significant (Fig. 2d). In uncontrolled terrain, the 15-year median reached a minimum in the 1990s in the four countries AUT (1995-1997), CHE (19931994), FRA (1985-1994), and ITA (1995-1998). With the exception of FRA, these were significant turning points in the time series. However, comparisons of the 15 years surrounding these low points and the final 15 years of the dataset 
(a) CHE, AUT, SVN: years 1950-2015

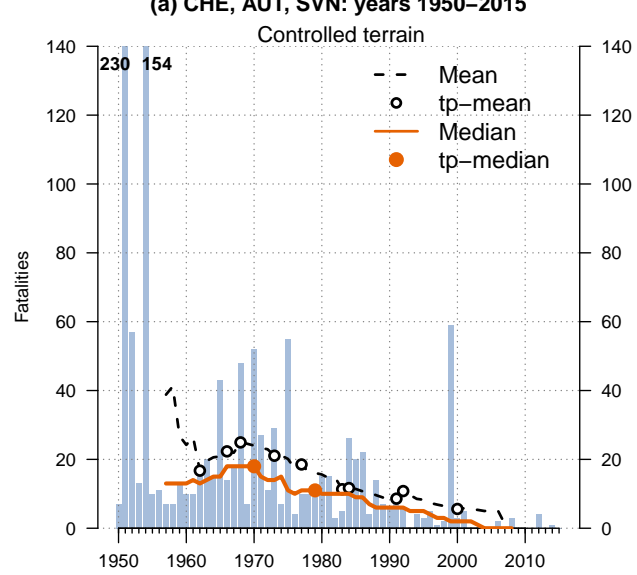

(c) European Alps: years 1970-2015

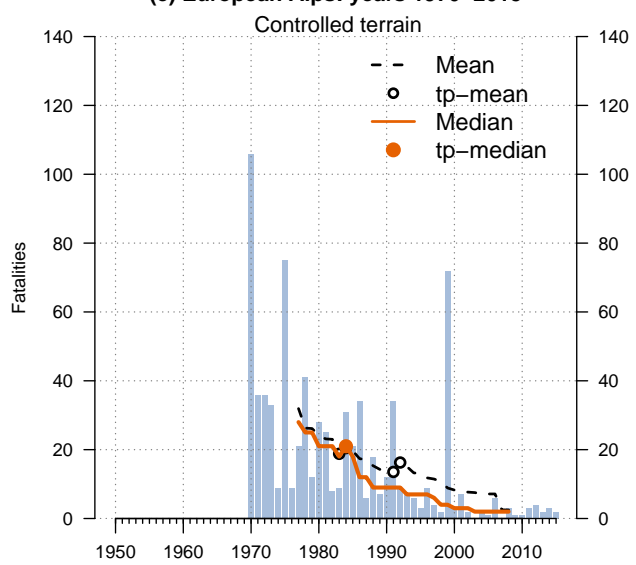

(b) CHE, AUT, SVN: years 1950-2015

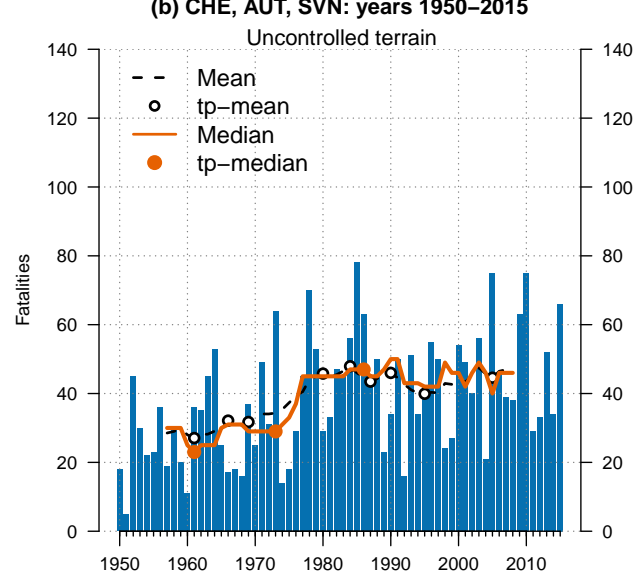

(d) European Alps: years 1970-2015

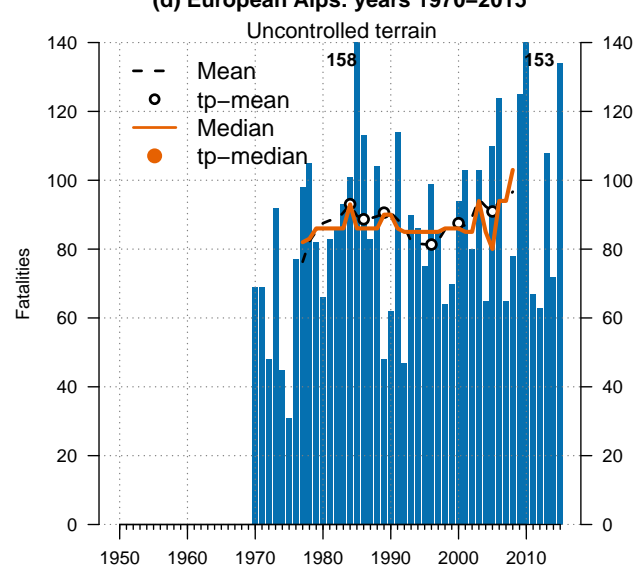

Figure 2. Avalanche fatalities for each hydrological year for two periods and the datasets controlled (left) and uncontrolled terrain (right): Switzerland, Austria, and Slovenia, 1950-2015 (upper plots) and the whole Alps, 1970-2015 (lower plots). The 15-year moving means and the 15-year moving medians are shown. Significant $(p<0.05)$ turning points $($ tp) for the mean and median curves are marked with circles. In years when the annual number of fatalities exceeded the limit of the selected $y$ axis, the fatality number is shown at the top of the bar.

indicated that the increase in fatalities that occurred in later years was never significant $(p>0.05)$. In all countries, most fatalities occurred in uncontrolled terrain (Table 2).

Corresponding to the opposing trends in controlled and uncontrolled terrain, the proportion of fatalities in uncontrolled terrain increased significantly from the first 15 years (1970-1984: $72 \%)$ to the last 15 years (2001-2015: $97 \%$, $p<0.001)$ of this period.

The 46-year time series from the combined datasets from FRA, ITA, LIE, and DEU was significantly cross-correlated $(p<0.01$, lag $=0$ years $)$ with the combined data from AUT, CHE, and SVN, as well as with the CHE subset $(p<0.01$, lag $=0$ years). Cross-correlation between the four countries with the highest number of fatalities (AUT, CHE, FRA, ITA) showed significant positive correlations between CHE and AUT as well as between CHE and ITA $(p<0.01)$, while CHE and FRA were not significantly correlated $(p=0.05)$. The AUT data showed no significant cross-correlation with the FRA and ITA time series, while FRA and ITA showed a significant cross-correlation $(p=0.02)$. When fatalities in controlled and uncontrolled terrain were each analysed individually between these countries, significant positive correlations were only found between CHE and AUT datasets $(p<0.05)$.

Inter-annual variability in the fatality numbers in uncontrolled terrain was significantly larger in the three easternmost countries (AUT; AUT, DEU, SVN combined) than in the other countries. In controlled terrain, the four countries with the most fatalities (AUT, CHE, FRA, ITA) showed similar inter-annual variability. 
4

\section{Discussion}

\subsection{Avalanche fatality data: statistical considerations}

Avalanche fatality statistics are generally highly influenced by a relatively small number of events, underreporting of non-fatal accidents, a potentially large influence of single multi-fatality accidents or extreme years and random effects. We addressed these issues by investigating and comparing the aggregated avalanche fatality data from the seven Alpine countries.

We consider the combination of the seven Alpine datasets appropriate because the Alps spans these countries and they have all undergone similar structural and economical changes in the investigated period (Bätzing, 2002). The Alpine countries were also the founding members of the ICAR-CISA in 1948 (except LIE, ICAR-CISA, 1998) and introduced together the European Avalanche Danger scale in 1993 (except LIE and SVN, Meister, 1994). Although Slovenia (SVN) was part of former Yugoslavia and became independent only in 1991, it also experienced an increase in winter tourism from the 1960s onwards (Pavšek, 2000). The European Alps are also considered as one "territory" (Alpine Convention, 2009, p. 1), covering a surface area of approximately $190000 \mathrm{~km}^{2}$, with a resident population of 14 million inhabitants and more than 100 million tourists visiting each year (Alpine Convention, 2009).

By applying 15-year running medians (and 15-year means) and including the largest-possible sample for each time series, we addressed issues like serial correlation (significant correlations with lags of up to 12 years) and high annual variability, and we reduced the influence of extreme events and years.

The annual fatality numbers of neighbouring countries were often correlated. We surmise that this is linked to large-scale weather and snowpack patterns leading to similar avalanche conditions over large parts of the Alps at the same time. Examples are the catastrophic winters of 1951 in Austria, Italy, and Switzerland (e.g. SLF, 1952; Roch, 1980) and 1999 in Austria, France, and Switzerland (e.g. Ancey et al., 2000; WSL, 2000; Höller, 2015). Similarly, Meister (2001) noted clusters of recreational accidents occurring on the same weekend throughout the Alps.

While many similarities in national statistics were noted, some significant differences existed. Annual variability in the fatality numbers was lower in the countries further west (for instance FRA, CHE) than in AUT (located to the east). This result highlights the importance of using sufficiently long periods to explore trends, particularly in the countries further east. Further, only the CHE data showed significant correlations with most of the other national statistics. We suspect this is due to the fact that the Swiss Alps are located in the "middle" of the Alps, sharing borders with all countries except SVN, and are influenced by the same weather and snowpack patterns as the neighbouring countries. This might also suggest that the observed changes in the CHE fatality numbers over time are an indicator of developments in the other Alpine countries prior to the period when data were available. However, we advise caution in applying this assumption prior to the years before 1945, when all countries - except CHE - were involved in World War II.

Similar long-term developments were observed in the fatality numbers in uncontrolled and controlled terrain in the four countries with the highest number of fatalities (AUT, CHE, FRA, ITA). This suggests that pronounced long-term trends may be investigated using national avalanche fatality statistics. However, if trends are only marginally significant, we advise consultation of statistics from neighbouring countries as a cross-reference.

Long-term statistics in the three countries with few avalanche casualties (DEU, LIE, SVN) are characterized by very small sample sizes (mean annual fatality numbers between 0.2 and 2.5) and inter-annual variability (CV) equal to or greater than the long-term mean (Table 2). In these countries, single events that are particularly severe have an even greater impact on summary statistics than in the other countries. As an example, the single worst accident in the German Alps (Zugspitze in 1965, 10 fatalities; not included in the analysis because it was outside the explored period) corresponds to more than $8 \%$ of the fatalities in DEU between 1970 and 2015. In comparison, the most tragic avalanche accident in France (Val d'Isère 1970, 39 fatalities), which caused almost 4 times as many fatalities as the accident in Germany, corresponds to about $3 \%$ of the fatalities in the French Alps during the same period. In contrast to single avalanche accidents resulting in numerous fatalities, which influence annual numbers strongly, statistics would be only marginally influenced by including fatalities from the lowerelevation mountain ranges north of the Alps (e.g. Black Forest/DEU - three fatalities since 1970; Kühnel, 2016) or from other mountain regions (e.g. in FRA the Vosges, Jura and Massif Central mountains (mean 0.5 fatalities/year) or the Pyrenees (2-3 fatalities/year); Goetz, 2011). However, careful consideration is necessary regarding which regions should be included and explored as one combined dataset when exploring avalanche fatality data. Differences between the low-elevation mountain ranges and the Alps include the number of accidents in controlled terrain, as well as the existence of publicly available avalanche forecasts and, possibly, avalanche awareness and education of the recreationists.

\subsection{Trend discussion}

The number of avalanche fatalities in the European Alps has remained relatively stable during the last 40 years, despite large inter-annual fluctuations. This corresponds to some of the previous publications exploring national statistics (e.g. CHE years 1937-1999, Tschirky et al., 2000; FRA 19722011, Jarry, 2011). Therefore, decreasing fatality numbers over time, as observed in CHE (1977-2006; Harvey and 
Zweifel, 2008) and ITA (1985-2009; Valt, 2009), may be due either to the length of the explored temporal window and/or to the limitation of national statistics. However, while exploring the Alpine fatality data as one dataset increases the robustness of the results, it may also smudge relevant trends in distinct regions.

Investigating fatality statistics by the location of the victim at the time of the avalanche, two distinctly different trends were noted. Avalanche fatalities in controlled terrain have decreased considerably since the 1970s, while avalanche fatalities in uncontrolled terrain showed a marked increase between the 1960s and 1980s, followed by no clear trend until 2015.

\subsubsection{Controlled terrain}

After 1970, fatality numbers in controlled terrain showed a significant downward trend, in both the 15-year running median (relatively independent of single extreme years), and in the frequency of extreme years. This positive trend has been recognized in previous publications (e.g. AUT 1968-2011 (Pfeifer et al., 2013) or SVN in the 20th century, Pavšek, 2002). This reduction in the fatality numbers may be explained by the successful implementation of prevention measures, such as the construction of avalanche defence structures, the regulation regarding building in avalanche-prone zones, and the application of active measures (e.g. the preventive artificial control of avalanches by explosives), or passive measures (e.g. temporary closures of threatened areas) (WSL, 2000; Fuchs et al., 2004; Höller, 2007). Finally, the implementation and training of local avalanche commissions may also have contributed to the successful reduction of avalanche fatalities in controlled terrain (Bründl et al., 2004; Etter et al., 2008; BKA, 1991). However, despite the extensive measures undertaken, widespread catastrophic avalanche situations may still occur as in the winter of 1999 when 72 people lost their lives in settlements or while travelling on transportation corridors throughout the Alps.

Outside the European Alps, similar declining trends have been noted in Canada and the United States (e.g. Stethem et al., 2003; Jamieson et al., 2010; Page et al., 1999).

\subsubsection{Uncontrolled terrain}

Avalanche casualties in uncontrolled terrain doubled between the 1960s and the 1980s, at a time when ski area development and winter tourism experienced an unprecedented boom period in the Alps, and when Alpine traffic and mobility of the population increased (Ancey et al., 1998; Bätzing, 2002; Meister, 2001).

While the number of recreationists in uncontrolled terrain is unknown, several authors (Valla, 1990; Sivardiére, 1998) have presumed that the number of winter recreationists has grown or even "exploded" (Jarry, 2011, p. 19) over the years. Indirectly, the increase in Alpine club members (e.g. Österreichischer Alpenverein, 2012) and the number of skiers and overnight tourists in ski resorts (Etter et al., 2008) also support this assumption. More recently, representative surveys of the Swiss population concerning their sport activity confirmed the increase in winter touring activities (Winkler, 2015).

Despite the increase in backcountry recreationists, the fatality numbers started to level off from the late 1970s onwards (Fig. $2 b$ and d). This coincides with the invention of new rescue technologies, most notably the avalanche transceiver (e.g. Good, 1972). This new technology revolutionized avalanche search and rescue. For the first time, companions had a means to rapidly locate fully buried and transceiver-equipped peers prior to the arrival of professional rescue teams. At the time, prevention measures emphasized the message to carry an avalanche transceiver, a shovel, and a probe (Valla, 1990). The increasingly widespread use of rescue equipment (e.g. Etter et al., 2008) helped to markedly raise the proportion of fully buried people located by companions (e.g. Techel, 2015), to drastically reduce average burial times and hence increase the survival rate of fully buried people (e.g. Tschirky et al., 2000; Brugger et al., 2007; Hohlrieder et al., 2008). Further technological developments such as the increasing use of radios and later of mobile phones for alarming organized rescue teams, as well as helicopter-assisted rescues and improved medical equipment, allowed professional rescue teams to respond more efficiently, administer first aid medical treatment already on site, and transport patients rapidly to hospitals for further treatment (Atkins, 2008; Mair et al., 2013). These technological developments in avalanche rescue were accompanied by continuous efforts to educate recreationists and professionals (Valla, 1984). Over the decades avalanche education, which initially focused on avalanche rescue, shifted to accident prevention (Etter et al., 2008). At the same time, regional coverage and distribution of publicly available avalanche forecasts increased.

The slight dip in the fatality numbers in uncontrolled terrain observed in Austria, France, Italy, and Switzerland in the 1990s, and visible also in other avalanche statistics (for instance in the number of fully buried people in the Swiss Alps; Techel, 2015), is somewhat surprising. Etter et al. (2008) suggested that the introduction of the reduction method and the $3 \times 3$ method (Munter, 1997) had a large influence at the time. However, it is unclear if this temporally limited reduction is statistically significant and what may have caused it.

A side effect of the increased recreational activity in snowcovered mountains may be the frequent disturbance of the snowpack (for instance of potential weak layers) by skiers, particularly on very popular ski touring routes or in close proximity to ski areas (e.g. Harvey et al., 2012). Although there is no direct evidence of this effect, we suspect that such disturbances may have contributed to a reduction of accidents in the most-frequently tracked terrain sections. Other changes, like a shift towards more ski tours being undertaken 
in mid-winter rather than in spring (Valt, 2009; Jarry, 2011) or a shorter snow season at mid-elevations due to climate change (Marty, 2008), may also have influenced the number of avalanche accidents in certain regions. However, we speculate that these factors have a rather minor influence on fatality numbers.

In contrast to the stabilization of fatality numbers in the European Alps, there is still an increase in recreational accidents in other regions, like in North America (e.g. Page et al., 1999). There, new backcountry user groups, for instance snowmobilers, contribute to a large proportion of the growing avalanche fatality numbers (e.g. Jamieson et al., 2010; Chabot, 2011). In the Alps, where snowmobiling away from ski areas is often not permitted, snowshoe hikers were responsible for a large proportion of the increase in backcountry usage in the most recent decade (Winkler, 2015). Consequently, the number of fatal accidents with snowshoe hikers also increased (e.g. Valt, 2009). While this user group was less avalanche-aware than backcountry skiers (Procter et al., 2013), snowshoe hikers also had a lower risk than backcountry skiers (Winkler, 2015) and therefore had a relatively small impact on overall fatality numbers. Such regionally different developments highlight two aspects: (i) the potentially large influence of new, initially largely avalanche-unaware and regionally distinct user groups on small total accident numbers and thus (ii) the need to explore accidents statistics in view of specific developments in different mountain regions.

\section{Conclusions}

For organizations involved in educating recreationists and avalanche professionals, as well as for policy makers deciding where additional investments in avalanche prevention are necessary, it is very important to know if trends in fatality numbers exist. However, it is challenging to discern between short-term variability and long-term trends in avalanche fatality statistics, which are characterized by high annual variability, small sample sizes (even if all national statistics are aggregated), a relatively large influence of single and particularly severe multi-fatality events, and random effects. We obtained novel datasets covering three periods between 1937 and 2015 that comprised the largest avalanche fatality dataset available for the region of the European Alps. We noted several trends:

i. The number of fatalities in settlements and on transportation corridors has reduced drastically since the 1970s in all Alpine countries.

ii. The number of fatalities in uncontrolled terrain almost doubled between the 1960s and the 1980s. Since then, numbers have remained relatively stationary with no further significant increase, despite a large increase in the number of winter backcountry recreationists. iii. Associated with these two opposing trends, we showed a shift towards avalanche fatalities almost exclusively occurring in uncontrolled terrain.

Further, the Swiss dataset, the longest time series, correlated best with the other Alpine countries and may thus be considered as a long-term indicator roughly reflecting the development in other Alpine countries.

We recommend exploring avalanche statistics in countries and regions with few fatal incidents over longer periods and/or in combination with statistics from neighbouring regions with comparable social and structural developments and legal regulations. Suitable combinations for the latter suggestion might be to investigate German and/or Slovenian data with Austrian statistics and to address avalanche fatalities in Liechtenstein with either Swiss or Austrian data. While we have discussed some plausible developments that potentially influence avalanche fatality numbers, their quantitative influence remains to be investigated. Finally, regardless of any technological developments, human involvement with an avalanche remains a potentially life-threatening event and thus the focus must remain on preventing accidents in the first place.

\section{Data availability}

Avalanche fatality data are collected by national organizations, who also have data sovereignty. Therefore, the organizations mentioned in Table 1 have to be contacted concerning access to the data. An additional source is the International Commission for Alpine Rescue (ICAR-CISA; http://www. alpine-rescue.org), which collects data on all avalanche fatalities in Europe and North America.

Acknowledgements. We thank Stephan Wohlwend (Amt für Bevölkerungsschutz Liechtenstein) for supplying the data for Liechtenstein and all collaborators who collected data concerning avalanche accidents in the various countries. We are additionally grateful to two anonymous reviewers and to Christoph Mitterer, Stephan Harvey, and Christine Pielmeier for their valuable feedback on the manuscript, and Melissa Dawes for reviewing the English language.

Edited by: E. Reynard

Reviewed by: two anonymous referees

\section{References}

Alpine Convention: The Alps: eight countries, a single territory, available at: www.alpconv.org (last access: 21 May 2016), 2009.

Ancey, C., Gardelle, F., and Gardelle, C.: L'homme face à la neige et aux avalanches dans les temps passés, in: Guide neige et avalanche, Connaissances, pratiques, sécurité, 21-34, Edisud. Ouvrage collectif sous le patronage de l'ANENA, 2nd edn., 1998. 
Ancey, C., Rapin, F., Martin, E., Coléou, C., Naaim, M., and Brunot, G.: L'avalanche de Péclerey du 9 février 1999, La Houille Blanche, 5, 45-53, 2000.

Atkins, D.: Time to change rescue attitudes for a new generation, in: Proceedings International Snow Science Workshop 2008, Whistler, Canada, 80-86, 2008.

Badoux, A., Andres, N., Techel, F., and Hegg, C.: Natural Hazard fatalities in Switzerland from 1946 to 2015, Nat. Hazards Earth Syst. Sci., in preparation, 2016.

Bätzing, W.: Der Stellenwert des Tourismus in den Alpen und seine Bedeutung für eine nachhaltige Entwicklung des Alpenraumes, Der Alpentourismus. Entwicklungspotenziale im Spannungsfeld von Kultur, Ökonomie und Ökologie, 175-196, 2002.

BKA: Gesetz vom 10. Oktober 1991 über die Lawinenkommissionen in den Gemeinden, available at: https://www.ris.bka.gv.at/GeltendeFassung.wxe?Abfrage= LrT\&Gesetzesnummer=20000172, Bundeskanzleramt, Rechtsinformationssystem, (last access: February 2016), 1991.

Boslaugh, S. and Watters, P.: Statistics in a nutshell. A desktop quick reference, O’Reilly Media, Inc., Sebastopol, 1st edn., 480 pp., 2008.

Brugger, H., Durrer, B., Adler-Kastner, L., Falk, M., and Tschirky, F.: Field management of avalanche victims, Resuscitation, 51, 7-15, doi:10.1016/S0300-9572(01)00383-5, 2001.

Brugger, H., Etter, H., Zweifel, B., Mair, P., Hohlrieder, M., Ellerton, J., Elsensohn, F., Boyd, J., Sumann, G., and Falk, M.: The impact of avalanche rescue devices on survival, Resuscitation, 75, 476-483, doi:10.1016/j.resuscitation.2007.06.002, 2007.

Bründl, M., Etter, H.-J., Steiniger, M., Klingler, Ch., Rhyner, J., and Ammann, W. J.: IFKIS - a basis for managing avalanche risk in settlements and on roads in Switzerland, Nat. Hazards Earth Syst. Sci., 4, 257-262, doi:10.5194/nhess-4-257-2004, 2004.

Bundesamt für Statistik: Verkehrsunfälle und Umweltauswirkungen (traffic accidents and environmental impact statistics), available at: http://www.bfs.admin.ch/bfs/portal/de/index/themen/11/ 06/blank/01/aktuel.html (last access: March 2016), 2016.

Chabot, D.: Promoting avalanche awareness in the snowmobile capital of the world, The Avalanche Review, 29, 14, 2011.

Edgerly, B.: Under the radar: exploiting new school media to capture unreported avalanche incidents, in: Proceedings International Snow Science Workshop 2010, Squaw Valley, CA, 304309,2010

Etter, H., Meister, R., and Atkins, D.: ICAR and its importance in avalanche rescue, in: Proceedings International Snow Science Workshop 2004, Jackson Hole, WY, 360-369, 2004.

Etter, H., Stucki, T., Zweifel, B., and Pielmeier, C.: Developments in avalanche forecasting and other prevention measures and their potential effects on avalanche fatalities, in: Proceedings International Snow Science Workshop 2008, Whistler, Canada, 628635, 2008

Fridstrom, L., Ifver, J., Ingebritsen, S., Kulmala, R., and Thomsen, L.: Measuring the contribution of randomness, exposure, weather, and daylight to the variation in road accident counts, Accid. Anal. and Prev., 27, 1-20, doi:10.1016/00014575(94)e0023-e, 1995.

Fuchs, S., Bründl, M., and Stötter, J.: Development of avalanche risk between 1950 and 2000 in the Municipality of Davos,
Switzerland, Nat. Hazards Earth Syst. Sci., 4, 263-275, doi:10.5194/nhess-4-263-2004, 2004.

Goetz, D.: Les avalanches mortelles dans les Vosges, le Jura et le Massif central, Neige et Avalanches, 133, 12-17, 2011.

Good, W.: Optimaler Einsatz der Mittel zur Ortung Lawinenverschütteter, in: Schnee und Lawinen in den Schweizer Alpen. Winter 1970/71, 154-161, Eidg. Institut für Schnee- und Lawinenforschung Weissfluhjoch Davos, 1972.

Grosjean, P. and Ibanez, F.: pastecs: package for analysis of spacetime ecological series, $r$ package version 1.3-18, 2014.

Haegeli, P., Falk, M., Procter, E., Zweifel, B., Jarry, F., Logan, S., Kronholm, K., Biskupič, M., and Brugger, H.: The effectiveness of avalanche airbags, Resuscitation, 85, 1197-1203, doi:10.1016/j.resuscitation.2014.05.025, 2014.

Harvey, S.: Avalanche incidents in Switzerland in relation to the predicted danger degree, in: Proceedings International Snow Science Workshop 2002, Penticton, Canada, 2002.

Harvey, S. and Zweifel, B.: New trends of recreational avalanche accidents in Switzerland, in: Proceedings International Snow Science Workshop 2008, Whistler, Canada, 9-15, 2008.

Harvey, S., Rhyner, H., and Schweizer, J.: Lawinenkunde, Bruckmann Verlag GmbH, München, 2012.

Hohlrieder, M., Thaler, S., Würtl, W., Völckel, W., Ulmer, H., Brugger, H., and Mair, P.: Rescue missions for totally buried avalanche victims: conclusions from 12 years of experience, High Alt Med Biol, 9, 229-233, doi:10.1089/ham.2007.1061, 2008.

Höller, P.: Avalanche hazards and mitigation in Austria: a review, Nat Hazards, 43, 81-101, doi:10.1007/s11069-007-91092, 2007.

Höller, P.: Lawinen - die grössten Katastrophen in Österreich seit 1946/47, Studia Universitätsverlag Innsbruck, 95 pp., 2015.

International Commission for Alpine Rescue ICAR-CISA, available at: http://www.alpine-rescue.org, last access: June 2016.

ICAR-CISA: 50 Jahre Internationale Bergrettung 1948-1998, available at: http://www.alpine-rescue.org (last access: May 2016), 1998.

ICAR-CISA: ICAR Avalanche Statistic 1983-2015. 20160115AVA Avalanche deaths by activity, official statistic, not openly accessible, 2016.

ILO: Improvement of national reporting, data collection and analysis of occupational accidents and diseases, International Labour Office, Geneva, 2012.

Jamieson, B. and Jones, A.: The effect of under-reporting of non-fatal involvements in snow avalanches on vulnerability, in: Proceedings 12th International Conference on Applications of Statistics and Probability in Civil Engineering, ICASP12, Vancouver, Canada, 2015.

Jamieson, B., Haegeli, P., and Gauthier, D.: Avalanche accidents in Canada, Volume 5, 1996-2007, Canadian Avalanche Association, 429 pp., 2010.

Jarry, F.: 40 ans d'accidents d'avalanche ... 40 ans de prévention, Neige et Avalanches, 135, 18-22, 2011.

Kirchsteiger, C.: Trends in accidents, disasters and risk sources in Europe, J. Loss. Prevent. Proc., 12, 7-17, doi:10.1016/s09504230(98)00033-3, 1999.

Kühnel, F.: Wenn Schnee zum Risiko wird, Badische Zeitung, 201602-13, list of avalanche fatalities in the Schwarzwald region since 1729, collected by Frank Kühnel, 2016. 
Laternser, M. and Pfister, C.: Avalanches in Switzerland 1500-1990, in: Rapid mass movement as a source of climatic evidence for the Holocene, Palaeoclimate Research, 19, 241-266, 1997.

Luzian, R.: Lawinenereignisse und Witterungsablauf in Österreich. Winter 1987/88, 1988/89, 1989/90, 1990/91, Österreichischer Agrarverlag, Wien: 188 Seiten (FBVA-Berichte, Nr. 68), 1992.

Luzian, R.: Lawinenschäden in Österreich in der Periode von 1967/68 bis 1992/93, in: Proceedings Interpraevent 2000, Villach, Austria, 437-450, 2000.

Mair, P., Frimmel, C., Vergeiner, G., Hohlrieder, M., Moroder, L., Hösl, P., and Völckel, W.: Emergency medical helicopter operations for avalanche accidents, Resuscitation, 84, 492-495, doi:10.1016/j.resuscitation.2012.09.010, 2013.

Mann, H.: Nonparametric tests against trend, Econometrica, 13, 245-259, doi:10.2307/1907187, 1945.

Margreth, S.: Die Wirkung des Waldes bei Lawinen, Forum für Wissen, 21-26, 2004.

Marty, C.: Regime shift of snow days in Switzerland, Geophys. Res. Lett., 35, 163-167, doi:10.1029/2008gl033998, 2008.

McCammon, I. and Hägeli, P.: An evaluation of rule-based decision tools for travel in avalanche terrain, Cold Reg. Sci. Technol., 47, 193-206, doi:10.1016/j.coldregions.2006.08.007, 2007.

McLeod, A.: Kendall: Kendall rank correlation and Mann-Kendall trend test, http://CRAN.R-project.org/package=Kendall, r package version 2.2, 2011.

Meister, R.: Lawinenniedergänge mit Todesopfern in der Schweiz, in: Schnee und Lawinen in den Schweizer Alpen. Winter 1985/86, 195-206, Eidg. Institut für Schnee- und Lawinenforschung Weissfluhjoch Davos, 1987.

Meister, R.: Country-wide avalanche warning in Switzerland, in: Proceedings International Snow Science Workshop 1994, Snowbird, UT, 58-71, 1994.

Meister, R.: Avalanches: warning, rescue, prevention, in: ICAR conference Makarska, Croatia 2001, p. 8, 2001.

Munter, W.: $3 x \times 3$ Lawinen, Agentur Pohl und Schellhammer, Garmisch-Partenkirchen, 1st edn., 1997.

Österreichischer Alpenverein: Jahresbericht 2012, available at: http://www.alpenverein.at/portal_wAssets/docs/der-verein/JB_ 2012_ebook.pdf (last access: March 2016), 2012.

Page, C., Atkins, D., Shockley, L., and Yaron, M.: Avalanche deaths in the United States: a 45-year analysis, Wilderness Environ Med., 10, 146-151, 1999.

Pavšek, M.: Les avalanches dans les Alpes slovènes, La leçon à tirer des précédents historiques, in: Histoire et mémoire des risques naturels, 149-164, Grenoble: Maison des Sciences de l'HommeAlpes, 2000.

Pavšek, M.: Snešni plazovi v Sloveniji (Avalanches in Slovenia), Geografija Slovenije 6, Ljubljana, 209 pp., 2002.

Pfeifer, C., Zeileis, A., and Höller, P.: Trend and regional analysis of fatal off-piste and backcountry avalanche accidents in Austria within the years 1968 and 2011, in: Proceedings International workshop on statistical modelling 2013, Palermo, Italy, 743-748, 2013.

Procter, E., Strapazzon, G., Dal Cappello, T., Castlunger, L., Staffler, H., and Brugger, H.: Adherence of backcountry winter recreationists to avalanche prevention and safety practices in northern Italy, Scand. J. Med. Sci. Sports, 24, doi:10.1111/sms.12094, 2013.
R Core Team: R: A language and environment for statistical computing, R Foundation for Statistical Computing, Vienna, Austria, available at: https://www.R-project.org/ (last access: March 2016), 2016.

Roch, A.: Neve e valanghe, Milano: Club Alpino Italiano, 1980.

Schaffhauser, H.: Lawinenereignisse und Witterungsablauf in Österreich. Winter 1986/87, Österreichischer Agrarverlag, Wien: 138 Seiten (FBVA-Berichte, Nr. 35), 1988.

Schweizer, J. and Lütschg, M.: Characteristics of humantriggered avalanches, Cold Reg. Sci. Technol., 33, 147-162, doi:10.1016/s0165-232x(01)00037-4, 2001.

Sivardiére, F.: Le secours en avalanche, in: Guide neige et avalanche. Connaissances, pratiques, sécurité, 277-295, Edisud. Ouvrage collectif sous le patronage de l'ANENA. 2nd edn., 1998.

SLF: Schnee und Lawinen in den Schweizer Alpen, Jahrgänge (Winter 1950/51 bis Winter 1979/80), Eidg. Institut für Schneeund Lawinenforschung Weissfluhjoch Davos, 1950-1980.

SLF: Schnee und Lawinen in den Schweizer Alpen. Winter 1950/51, Eidg. Institut für Schnee- und Lawinenforschung Weissfluhjoch Davos: 231 pages (Nr. 15), 1952.

Stethem, C., Jamieson, B., Schaerer, P., Liverman, D., Germain, D., and Walker, S.: Snow avalanche hazard in Canada - a review, Nat Hazards, 28, 487-515, doi:10.1023/A:1022998512227, 2003.

Techel, F.: Die Überlebenschancen sind gestiegen, Bergretter, 32, $10,2015$.

Techel, F. and Zweifel, B.: Recreational avalanche accidents in Switzerland: trends and patterns with an emphasis on burial, rescue methods and avalanche danger, in: Proceedings International Snow Science Workshop 2013, Grenoble, France, 1106-1112, 2013.

Techel, F., Zweifel, B., and Marty, C.: Schnee und Lawinen in den Schweizer Alpen. Hydrologisches Jahr 2014/15, WSL Institut für Schnee- und Lawinenforschung SLF Davos: 83 pages (WSL Ber. 37), 2015a.

Techel, F., Zweifel, B., and Winkler, K.: Analysis of avalanche risk factors in backcountry terrain based on usage frequency and accident data in Switzerland, Nat. Hazards Earth Syst. Sci., 15, 1985 1997, doi:10.5194/nhess-15-1985-2015, 2015.b.

Tschirky, F., Brabec, B., and Kern, M.: Avalanche rescue systems in Switzerland: experience and limitations, in: Proceedings International Snow Science Workshop 2000, Big Sky, MT, 369-376, 2000.

Valla, F.: The french experience in avalanche education for skiers, in: Proceedings International Snow Science Workshop 1984, Aspen, CO, 70-77, 1984.

Valla, F.: Les accidents d'avalanches dans les Alpes 1975-1989, Revue de géographique alpine, 78, 145-155, 1990.

Valt, M.: Incidenti da valanga sulle Alpi 1985-2009, Neve e Valanghe, 68, 14-23, 2009.

Valt, M. and Pivot, S.: Avalanche accident documentation is of fundamental importance to understand the dynamics, taking place in snow, of risky activities in order to implement the best possible prevention strategies, in: Proceedings International Snow Science Workshop 2013, Grenoble, France, 1142-1147, 2013.

Venables, W. and Ripley, B.: Modern Applied Statistics with S, Springer-Verlag, doi:10.1007/978-0-387-21706-2, 2002. 
Winkler, K.: Entwicklung des Lawinenrisikos bei Aktivitäten im freien Gelände, in: Lawinen und Recht. Tagungsband zum Internationalen Seminar vom 1.-3. Juni 2015, Davos, Switzerland, 109-112, WSL Ber 34, 2015.
WSL: Lawinenwinter 1999. Ereignisanalyse (Avalanche winter 1999. Event analysis.), WSL Institute for Snow and Avalanche Research SLF, 588 pp., 2000. 